\title{
"Jesteśmy połączonym z sobą światem" - Timothy Morton i widmo innej wspólnoty
}

Andrzej Marzec

TEKSTY DRUGIE 2018, NR 2, S. 88-101

DOI: $10.18318 /$ td.2018.2.6

$\mathbf{T}$ imothy Morton wpisuje się w nurt myślenia o ekologii, która zamiast powracać do Natury, stara się od niej odejść, czyli zrezygnować z tego problematycznego pojęcia, funkcjonującego najczęściej jako pojemnik na ideologię i służącego uzasadnianiu dowolnego prawa lub normy nazywanych naturalnymi ${ }^{1}$. Filozof odrzuca romantyczną wiarę w istnienie nieskalanej, harmonijnej, pięknej, dziewiczej i w konsekwencji dzikiej Natury oraz tworzy projekt ciemnej ekologii (dark ecology), która nie postuluje powrotu do czystości, gdyż nie ma kryterium piękna. Utrzymywanie pojęcia Natury przez długi czas służyło również podtrzymywaniu komfortowego dla

1 Więcej o tak zwanych strategiach ekomimetycznych, czyli dyskursywnym wytarzaniu Natury zob. T. Morton Ecology without Nature: Rethinking Environmental Aesthetics, Harvard University Press, Cambridge, London 2007. Należy w tym miejscu podkreślić, że Morton nie jest pierwszym myślicielem ani jedynym, który proponuje odwrót od pojęcia Natury - szerzej na ten temat m.in. w: Philosophy After Nature, Rowman \& Littelfield, ed. by R. Braidotti, R. Dolphijn, LondonNew York 2017. 
człowieka dystansu, czyli dramatycznego w skutkach podziału na ludzi kulturalnych oraz naturalnych nie-ludzi, których można było dzięki temu posiadać na własność i eksploatować. Chciałbym podążyć ścieżką zarysowaną przez Mortona i zapytać o przyczyny tego rozdzielenia, a także pokazać, dlaczego i w jaki sposób nie-ludzie znikają nam zazwyczaj z oczu. Moim celem będzie ujawnienie porządku symbiotycznego i próba zarysowania możliwości nowej, innej wspólnoty. Morton, zastanawiając się nad tym, co oznacza bycie człowiekiem, twierdzi, że nigdy nie jesteśmy do końca sobą, gdyż tworzą nas nie-ludzie, o których istnieniu chcielibyśmy zapomnieć. Bycie ludzkim, opierające się na wspólnocie, życzliwości, solidarności, przyjaźni i symbiozie, możliwe jest tylko dzięki połączeniu z tym, co nie-ludzkie.

\section{Znikanie i pojawianie się nie-ludzi}

Współcześni myśliciele, zmęczeni tradycyjnym przypisywaniem człowiekowi wszelkiej sprawczości, zaczęli w różny sposób upominać się o znikających w niewyjaśnionych, lecz zawsze antropocentrycznych okolicznościach nie-ludzi. Bruno Latour, aby przybliżyć i wyjaśnić ten niepokojący proces, posługuje się modelem czarnej skrzynki, w której niczym w przepastnej czarnej dziurze rozpływają się i giną rozmaici aktorzy dnia codziennego ${ }^{2}$. Aby wyjaśnić, w jaki sposób działają Latourowskie, złowrogie czarne skrzynki, wystarczy posłużyć się przykładem ciasta drożdżowego.

Nie od dziś wiadomo, że pieczenie ciast nie jest łatwą sztuką, dlatego częstując gości naszym wypiekiem, najczęściej zwracamy uwagę na to, że jest to wyrób „własnoręczny”, a pytani o przepis, nie mamy ochoty go zdradzać, mówiąc, że to nasza sekretna, oryginalna receptura. Podkreślając w ten sposób wyjątkowość naszego piekarskiego dzieła, a przez to również nas samych, jednocześnie unieważniamy milczących, lecz niezwykle pracowitych wspólników, bez których nigdy by się nam nic nie upiekło. Możemy oczywiście przyznać się, że lekko zmodyfikowany przepis otrzymaliśmy od naszej Babci, a jaja kupiliśmy w gospodarstwie Pana Henryka, ale to nadal nic nie zmieni w opowieści, w której jedynymi sprawcami wydarzeń są ludzie.

Przy ujawnianiu istnienia oraz pracy nie-ludzi, czyli rozpakowywaniu czarnej skrzynki, pomocne będzie wyobrażenie sobie, że pieczenie ciasta nie

2 Zob. B. Latour Dajcie mi laboratorium a poruszę świat, przeł. K. Abriszewski, Ł. Afeltowicz, „Teksty Drugie" 2009 nr 1/2, s. 163-192 oraz G. Harman Książe sieci: Bruno Latour i metafizyka, przeł. G. Czemiel, M. Rychter, Fundacja Augusta hr. Cieszkowskiego, Warszawa 2016, s. 60-79. 
jest wcale czynnością rutynową i powtarzalną (zamkniętą czarną skrzynką), ale jest czymś, co robimy pierwszy raz w całej historii piekarstwa. Rozpakowujące pytanie: „jak to jest zrobione?", można również zadać w inny sposób: „kto tak naprawdę napracował się przy cieście drożdżowym?”. Właściwie od razu po wejściu do kuchni okazuje się, że nie jesteśmy w stanie upiec ciasta drożdżowego samodzielnie. Aby osiągnąć upragniony przez nas cel, musimy pozyskać odpowiednich, strategicznych sojuszników, których całe szczęście znajdujemy w drożdżach.

Jednak samo ich odnalezienie nie oznacza jeszcze wcale tego, że te będą chciały z nami współpracować. Musimy zatem najpierw wzbudzić zainteresowanie drożdży naszą ofertą, aby te z kolei mogły przejąć nasze interesy (upieczenie ciasta), co Latour nazywa fachowo delegacją do czynników pozaludzkich. Dlatego zanim wejdziemy w owocną współpracę z drożdżami, musimy wcześniej dowiedzieć się, na jakich dokładnie warunkach zechcą dla nas żyć i pracować. W wyniku podjętych przez nas negocjacji okaże się, że optymalnymi warunkami są dla nich ciepło (nieprzekraczające $40^{\circ} \mathrm{C}$ ), brak przeciągów oraz umieszczenie w roztworze cukru i mleka. Dopiero wówczas, gdy zdecydujemy się spełnić te niezbyt wygórowane z perspektywy ludzkiej żądania, ofiarujemy drożdżom poczucie bezpieczeństwa, radość życia i chęć do rozmnażania się (pączkowania), a sami będziemy mogli cieszyć się drożdżowym (czyli zrobionym przez drożdże) ciastem.

Z kolei Graham Harman zwraca uwagę na antropocentryczne strategie rozpraszania przedmiotów, których indywidualność znika w momencie, gdy zostają sprowadzone do wielości (serii), zbioru posiadanych jakości lub wywoływanych skutków, czy też zredukowane do materii i atomów ${ }^{3}$. Harman, aby ukazać problem znikania nie-ludzi, nie posługuje się wprost Latourowskim pojęciem czarnej skrzynki, lecz odwołuje się do analiz struktury narzędziowości odnalezionych u Martina Heideggera. Niemiecki filozof twierdzi, że manipulatywno-użytkowy charakter bycia jest podstawowym sposobem funkcjonowania zatroskanego człowieka w świecie, który rozpoznaje inne byty na swojej drodze przede wszystkim jako narzędzia ${ }^{4}$. Heidegger uważa, że narzędzia zazwyczaj są niewidoczne, gdyż jako poręczne (zuhanden) i wykonujące zleconą im pracę, jednocześnie znikają zakryte posługującą się nimi

3 Zob. G. Harman Traktat o przedmiotach, przeł. M. Rychter, Wydawnictwo Naukowe PWN, Warszawa 2013.

4 Zob. M. Heidegger Bycie i czas, przeł. B. Baran, Wydawnictwo Naukowe PWN, Warszawa 1994, s. 96. 
ludzką ręką. Przedmiot ujawnia swoją obecność jedynie wtedy, gdy psuje się i zaczyna działać wadliwie. Wówczas, jako nieprzydatny, wyjątkowo pojawia się przed ręką (vorhanden), przechodząc tym samym z obszaru praktyki do sfery teoretycznego oglądu.

Heideggerowskie wycofywanie się w po(d)ręczność, czyli znikanie narzędzia w trakcie wykonywanej czynności, jest jednym z najbardziej interesujących i inspirujących wątków, które podejmuje w swoich filozoficznych rozważaniach Harman. Okazuje się bowiem, że większość pracowitych nie-ludzi pozostaje na co dzień właśnie w takim stanie wycofania, skazana tym samym na niewidzialność lub przeoczenie. Twórca realizmu spekulatywnego wskazuje na jeszcze jedną ciekawą cechę przedmiotów, które w jego ujęciu przestają być całkowicie dostępne ludzkiemu poznaniu, lecz pozostając w cieniu (wycofane), jednocześnie skrywają prawdę o sobie samych. Latour i Harman dochodzą do podobnych wniosków związanych z ontologicznym statusem nie-ludzi, na których również opiera swoje ekologiczne myślenie Morton. Żaden byt nie posiada uprzywilejowanego statusu, w taki sam sposób istnieje człowiek, mysz, trawa, robot kuchenny i szczoteczka do zębów. Żyjemy w najbardziej egalitarnym wszechświecie z możliwych, lecz ta wiadomość z ogromnym trudem daje się pomyśleć przez przyzwyczajonego do swej niczym nieuzasadnionej wyjątkowości człowieka.

\section{Zerwane więzi}

Timothy Morton zwraca uwagę na to, że moment wejścia człowieka w dorosłość, czyli tzw. osiągnięcie dojrzałości, niesie ze sobą nie tylko wymóg poprawnego, ale przede wszystkim radykalnego i konsekwentnego odróżniania świata ludzi od nie-ludzi ${ }^{5}$. Literaturę dla dorosłych możemy rozpoznać m.in. dzięki temu, że nie znajdziemy na jej kartach mówiących tosterów, zmywarek, śrubokrętów i zwierząt, gdyż jedynymi rozmawiającymi w jej przypadku bohaterami, nawet jeśli rzadko z tej okazji korzystają, są tutaj ludzie. Bycie dorosłym według amerykańskiego filozofa wiąże się bezpośrednio z traumatycznym oddzieleniem i katastrofalnym w skutkach zerwaniem ludzkich więzi z nie-ludźmi (The Severing). Wydarzeniem trudnym do jednoznacznego umiejscowienia w czasie i przestrzeni (zwłaszcza jeśli czas postrzegamy linearnie), lecz determinującym nasze codzienne zachowania i kształtującym

5 Zob. T. Morton Humankind: Solidarity with Nonhuman People, Verso, London-New York 2017, S. 24 . 
nasze doświadczenie teraźniejszości. Prawdopodobnie właśnie dlatego większość ludzi po chwilowym zachwycie dorosłością oraz jej złudnymi przywilejami zazwyczaj żałuje, że nie może już powrócić do ekscytującego, wypełnionego nieprzebraną rzeszą realnych stworzeń i wyimaginowanych stworów okresu dzieciństwa ${ }^{6}$.

Morton celowo odwołuje się do dziecięcej wyobraźni, gdyż posiada ona egalitarny i nieantropocentryczny charakter, zawsze ujawniając obecność innych, których istnienie dzięki rutynie i powtarzalności naszych działań nauczyliśmy się ignorować. Dorosły najczęściej zwraca uwagę jedynie na ludzką aktywność, podmiotową sprawczość, a przez to przykrywa i unieważnia wysiłki wielości nie-ludzi, za każdym razem ciężko pracujących na sukces, pod którym podpisuje się wyłącznie ludzka jednostka. Tymczasem świat dzieci do tego stopnia wypełniony jest działającymi w rozmaity sposób zwierzętami, przedmiotami, roślinami i istotami nadprzyrodzonymi (wróżki, duchy, potwory, elfy...), żeludzka sprawczość nie musi przyjmować w nim wcale wyjątkowych, imponujących, by nie powiedzieć monstrualnych rozmiarów. Warto przypomnieć sobie wrażliwość dziecka, które rozmawia z każdym napotkanym na spacerze zwierzęciem, jak z równym sobie, oraz jest zafascynowane możliwością kontaktu z niezwykle ciekawymi nie-ludźmi. Okazuje się jednak, że traktowanie nie-ludzi po ludzku, czyli na równi z ludźmi, w okresie naszej dorosłości może być co najmniej ryzykowne, gdyż wiąże się najczęściej z oskarżeniami o zdziecinnienie, diagnozami intelektualnego regresu czy nawet postępującego szaleństwa. Obawiam się, że jesteśmy w stanie poradzić sobie z tymi zarzutami i jednocześnie wyeksponować pozostającą do tej pory w cieniu, nie-ludzką działalność.

\section{Porządek symbiotyczny}

Jeśli solidarne trzymanie strony nie-ludzi oraz odbudowywanie więzi z nimi, tworzenie splotu wydaje się dziecinne, szalone lub naiwne, to być może warto pójść dalej tym tropem. Dlatego zradykalizujmy, poszerzmy tok naukowych rozważań, aby włączyć do nich to, co pozostawało do tej pory nie do

6 Warto zwrócić uwagę na to, że metodą podobną do metody Mortona w swojej twórczości posługuje się polski rysownik Karol "KRL” Kalinowski. Artysta w komiksach („Łauma” - 2009 oraz "Kościsko" - 2016) odwołuje się do dzięcięcej wyobraźni po to, aby wypełnić nie-ludzkimi istnieniami pochodzącymi ze słowiańskiej mitologii wydawałoby się wyludnione przestrzenie suwalskich ostępów leśnych, pustkowi i wsi. Całe wspólnoty mitologicznych stworów i ich skomplikowane losy mogą zostać zauważone jedynie przez dziecięce lub po prostu nieantropocentryczne oko. 
pomyślenia, jako zbyt błahe, ckliwe i infantylne. Chciałbym, żebyśmy przyjrzeli się disneyowskiej bajce Pocahontas (1995), aby dostrzec w niej nie tylko manifest ontologii zorientowanej na przedmioty (object-oriented ontology/ OOO), ale również próbę wytworzenia innej wspólnoty obejmującej ludzi i nie-ludzi. Mam nadzieję, że zawieszenie władzy dorosłości i powiązanie ze sobą dyskursu bajkowego i naukowego w obrębie porządku symbolicznego umożliwi również połączenie tego, co do tej pory konsekwentnie chcieliśmy rozdzielać, czyli pozwoli ujawnić porządek symbiotyczny.

Jesteśmy przyzwyczajeni do tego, aby Pocahontas odczytywać w sposób antropocentryczny i konwencjonalny. Nauczeni traktować ją niczym Romea iJulię, jak kolejną historię o zakochanych, opowiadającą o nieszczęśliwej, niemożliwej i niespełnionej miłości, która w żaden sposób nie może się między nimi wydarzyć. Jeśli jednak zdecydujemy się spojrzeć na nią w inny niż dotychczas sposób, wówczas okaże się, że główny dramat tej opowieści nie polega wcale na rozłączeniu pary ludzkich kochanków, lecz raczej na katastrofalnym rozdzieleniu świata ludzi i nie-ludzi.

John Smith, angielski kolonizator o blond włosach, który wraz z grupą poszukiwaczy złota przypływa statkiem do Ameryki, funkcjonuje w naszej interpretacji jako orędownik klasycznej, kontynentalnej filozofii. Biały, heteroseksualny mężczyzna z klasy średniej, antropocentryk (Kant, Hegel, Heidegger...), oprócz obowiązkowej strzelby, zostaje uzbrojony w śnieżnobiały uśmiech dandysa, który ma za zadanie zrównoważyć, oswoić i ozdobić wdziękiem osobistym każdą szowinistyczną myśl zrodzoną w jego umyśle. Smith okazuje się wiernym wyznawcą tradycji oświeceniowego indywidualizmu, gdyż od razu po przybiciu do brzegu odłącza się od grupy i udaje się na rekonesans. Sam, na własną rękę, niczym wytrawny zdobywca penetruje ostępy leśne, dokonując przy tym czynności poznawczych. Można zaryzykować tezę, że w podobny sposób powstawały Drogi Lasu Heideggera, który, opuszczając swoją chatę i samotnie wędrując leśnymi ścieżkami Schwarzwaldu, nieopodal Todtnauberga, nigdy nie pomyślał o tym, że można rozmawiać z drzewami.

Tymczasem Pocahontas funkcjonuje przede wszystkim, jako nieprzejednana rzeczniczka nie-ludzi (alter ego Timothy'ego Mortona). Bynajmniej nie dlatego, że żyje w zgodzie z Naturą bądź ma do niej uprzywilejowany dostęp, gdyż nasza bohaterka nie posługuje się wcale tą problematyczną kategorią. Należy podkreślić, że wytwarzanie (za pomocą ekomimetycznych strategii, które krytykuje Morton) i utrzymywanie ahistorycznego pojęcia Natury służy

7 Zob. T. Morton Humankind: Solidarity with Nonhuman People, s. 13. 
przede wszystkim ukrywaniu w niej nie-ludzi, unieważnianiu ich działalności oraz sprowadzaniu ich do naturalnie zachodzących procesów ${ }^{8}$. Pocahontas, w przeciwieństwie do jej europejskiego gościa, cechuje brak indywidualizmu oraz szczera niechęć do separacji, czyli utrzymywania granicy między tym, co ludzkie i nie-ludzkie. Dzięki temu nie jest w stanie nigdy odczuwać samotności lub izolacji, ponieważ nieustannie znajduje się w towarzystwie innych: nie opuszczają jej nawet na krok szop Meeko, koliber Flit oraz duchy przodków. Pocahontas zaskakuje również dlatego, że zwracając się z wyrzutem i niemałą dawką ironii do Johna Smitha, nie tylko krytykuje jego system wiedzy, ale trzeba przyznać, że robi to śpiewająco:

Ty masz mnie za głupią dzikuskęe, lecz choć cały świat zwiedziłeś, zjeździłeś wzdłuż i wszerz i mądry jesteś tak, że aż słów podziwu brak, dlaczego - powiedz mi - tak mało wiesz? Mało wiesz...

Pocahontas rozpoczyna od krytyki galopującego antropocentryzmu, który według niej jest po prostu wymagającym naprawienia błędem poznawczym. Wskazuje na to, że założycielska dla humanizmu opowieść o wywyższeniu i wyjątkowości białego człowieka/mężczyzny opiera się w gruncie rzeczy na poniżaniu innych oraz konsekwentnym odbieraniu im wartości. Dlatego jeśli przyznaje się otwarcie do swoich różnorodnych relacji z nie-ludźmi, skazana jest jednocześnie na odmówienie jej racjonalności oraz bycie częścią Natury, która według antropocentrycznej narracji nie myśli i nie jest kreatywna, lecz odtwarza odwieczne prawa i korzysta z gotowych algorytmów.

Morton w kontekście argumentu o uprzywilejowującej człowieka wyobraźni, której posiadanie miałoby usprawiedliwiać ludzkie pragnienie sprawowania władzy nad nie-ludźmi, przypatruje się twierdzeniu znalezionemu u Karola Marksa. Według autora Kapitału nawet najlepsza z pszczół nigdy nie będzie lepsza od najmniej zdolnego na świecie architekta, gdyż nie jest w stanie niczego sobie wyobrazić, lecz jedynie odtwarzać ${ }^{10}$. Morton zwraca uwagę,

8 Zob. T. Morton Ecology without Nature, s. 89.

9 Stawianie znaku równości między Pocahontas i Timothym Mortonem ma również sens dlatego, że jego myślenie, które nie uznaje zasady sprzeczności, często uznawane jest przez bardziej zdyscyplinowanych filozofów za zbyt dzikie, nieokrzesane i anarchiczne. Morton cieszy się powodzeniem przede wszystkim w awangardowym świecie sztuki (Björk, Olafur Eliasson, Hans Ulrich Obrist, Philippe Parreno). 
że niektórzy naukowcy będą starali się za wszelką cenę znaleźć dowody na to, że pszczoły jednak używają wyobraźni. Jednak jego zdaniem zdecydowanie bardziej skuteczne jest zaproponowanie innego twierdzenia: nikt nie jest w stanie udowodnić tego, że człowiek posługuje się wyobraźnią.

Z tego pomysłu korzysta błyskotliwa Pocahontas, gdy zarzuca Johnowi Smithowi właśnie brak wyobraźni, czyli coś, czego nigdy by się nie spodziewał usłyszeć, trafiając tym samym w jego najbardziej czuły punkt. Orędowniczka płaskich ontologii drwi sobie z kosmpolityzmu i światowości filozofa-podróżnika, który przekraczając bez trudu wszelkie granice, najważniejszą z nich (antropocentryczną) nosi w sobie, a ta pozwala mu wciąż dyskryminować, odróżniać ludzi od nie-ludzi. Jak się niebawem okaże, jedną z fundamentalnych różnic, która przeszkadza w zjednoczeniu pary nieszczęśliwych kochanków, jest odmienna koncepcja świata. Zanim jednak ten dysonans poznawczy ujawni się w całej okazałości, wcześniej Pocahontas w zdecydowany sposób krytykuje wyeksploatowaną do cna heideggerowską kategorię rozumienia.

\section{Heidegger vs. nie-ludzie}

Okazuje się, że niezmiennie, z wyjątkowo antropocentrycznym uporem uznajemy rozumienie (język) za najlepszy z możliwych, a przez to uprzywilejowany sposób dostępu do rzeczywistości. Powtarzamy w ten sposób do znudzenia szowinistyczny i męczący już błąd Heideggera, który starał się nas przekonać, że zwierzęta nie posiadają dostępu do bytu jako takiego czy też śmierci jako śmierci. Dlatego zgodnie z poglądami niemieckiego filozofa, w zdaniu „jaszczurka leży na skale”, powinniśmy przekreślić wyraz skała, co miałoby jednoznacznie wskazywać na to, że jaszczurka nie zdaje sobie sprawy z tego na czym leży, gdyż nie jest w stanie nazywać rzeczy ${ }^{11}$. Zwierzęcość (jeśli istnieje w ogóle taki rodzaj bytu) według Heideggera, w związku z brakiem języka, charakteryzowałaby się specyficznym rodzajem otępienia (Benommenheit), byciem osłupiałym bądź oniemiałym. Między innymi z tego powodu filozof decyduje się na opisanie zwierzęcia jako wybrakowanego, a zatem ubogiego w świat (Weltarm).

John Smith uznaje siebie za światowca nie tylko dlatego, że jest podróżnikiem, ale również w sensie heideggerowskim. Twierdzi, że jego doświadczenie świata zapośredniczone poprzez język jest najlepsze i najpełniejsze

11 Por. J. Derrida O duchu: Heidegger i pytanie, przeł. B. Brzezicka, Wydawnictwo Naukowe PWN, Warszawa 2015, s. 60-64. 
z możliwych. Jak gdyby gryzienie, lizanie, ocieranie, wąchanie, drapanie pazurami i drążenie podziemnych kanałów miało być wybrakowanym sposobem uczestniczenia w świecie ${ }^{12}$. Wydaje się, że Smith dopływa do „Nowego Świata", ale jedyne czym dysponuje, to stara, zaściankowa i ograniczająca kategoria antropocentrycznego świata. Dlatego Pocahontas/Morton najpierw rozprawia się z heideggerowską wizją rzeczywistości („Ty myślisz, że są ludźmi tylko ludzie, których ludźmi nazywać chce twój świat..."). Następnie zadaje Smithowi pytania, na które ten nie tylko nie zna odpowiedzi, ale sam nigdy nie potrafiłby ich sformułować, uwięziony w obrębie paradygmatu antropocentrycznego („Czy wiesz, czemu wilk tak wyje w księżycową noc? I czemu ryś tak zęby szczerzy rad?").

Okazuje się, że świat nigdy nie był wyłącznie ludzkim przywilejem, wynikającym ze sprawnego posługiwania się językiem, jak chciałby tę sprawę widzieć Heidegger/Smith. Należy przyznać, że człowiek nie należy wcale do wyjątków i nie tylko nie jest jedynym, który wytwarza świat (worlding), ale również nie robi tego najlepiej - w różny sposób tworzy go właściwie każda istota (nawet głaz). Niegdyś ekskluzywne i nobilitujące pojęcie świata współcześnie uległo niespodziewanej pauperyzacji, można nawet powiedzieć, że w tym momencie nie ma bardziej dostępnej i taniej idei na rynku filozoficznych koncepcji. Dzieje się tak dlatego, że każdy ze światów, również ludzki, jest z konieczności niekompletny - nie istnieje żaden uprzywilejowany (językowy bądź pozajęzykowy) dostęp do rzeczywistości w jej całości ${ }^{13}$. Dzięki temu, że każdy z ludzi i nie-ludzi ma podobnie niedoskonały, podziurawiony dostęp do świata, nie musimy zajmować się podporządkowywaniem innych, lecz raczej solidarną współpracą.

Zanim Pocahontas zdradzi wybrankowi swojego serca nadrzędną zasadę ontologii zorientowanej na przedmioty, wcześniej musi zwrócić uwagę na jego posesywne, kolonizujące skłonności, które nie tylko niszczą związki międzyludzkie, ale również okazują się niezwykle szkodliwe w relacjach z nie-ludzmi.

Na lądzie - gdy rozglądasz się - lądując, chcesz wszystko mieć na własność, nawet głaz, a ja wiem, że ten głaz ma także duszę, imię ma i zaklęty w sobie czas.

Zob. T. Morton Humankind:Solidarity with Nonhuman People, s. 20.

13 Zob. tamże, s. 83-84. 
Pocahontas zwraca uwagę na to, że główna zasada, jaką posługuje się Smith, czyli prawo własności prywatnej, służące do podporządkowywania sobie nie-ludzi, jest jednym z najbardziej destrukcyjnych zachowań. Nie chodzi przy tym o to, aby nadawać nie-ludziom prawa, lecz po prostu nie należy ich sobie przywłaszczać. Pojęcie własności prywatnej wiąże się z niebezpiecznym przekonaniem, że jeśli coś do nas należy, wówczas możemy tym dowolnie rozporządzać i zrobić dosłownie wszystko (zniszczyć, zepsuć, zabić) ${ }^{14}$. Tymczasem nikt nie posiada nikogo na własność i dotyczy to również samego pojęcia świata, który współtworzymy zawsze z innymi.

Morton upatruje przyczyny wielkiego rozdzielenia (The Severing) ludzi i nie-ludzi w powstaniu rolnictwa 12 tysięcy lat temu oraz w jego bezkonkurencyjnym rozwoju w czasach rewolucji neolitycznej, dlatego współczesnych ludzi nazywa potomkami rolników z Mezopotamii (Żyzny Półksiężyc). Przejście od kolektywów zbieracko-łowieckich do wspólnot opartych na działalności rolniczej uznaje za katastrofalne w skutkach, a specyficzny, antropocentryczny sposób myślenia, który się wówczas narodził, związany również $\mathrm{z}$ odpowiednim zarządzaniem ziemią, nazywa agrologistyką (agrilogistics) ${ }^{15}$. Używanie ziemi i zarządzanie nią jako prywatną własnością wzmacnia destrukcyjny nawyk posiadania, blokuje myślenie o współegzystencji oraz uniemożliwia ludzką solidarność z nie-ludźmi. Część z nich zostaje udomowiona, natomiast reszta zostaje wykluczona i nazwana szkodnikami. Agrologistyka, wynikająca bezpośrednio z rolnictwa, przyczyniła się według Mortona do rozpowszechnienia patriarchatu, zubożenia/wyjałowienia gleby, wzmocnienia społecznej hierarchii i do globalnego ocieplenia. Ważne jest również to, że od tej pory przestrzeń społeczna, która nie należała nigdy jedynie do człowieka, zostaje przez niego zawłaszczona i wzięta w posiadanie.

Jedną z proponowanych przez Pocahontas/Mortona dróg wyjścia z tej sytuacji jest porzucenie idei Natury, w której znikają rozpuszczeni nie-ludzie (w podobny sposób jak w czarnej skrzynce Latoura lub podręczności Heideggera/Harmana). Utrzymywanie fikcji związanej z istnieniem odwiecznej, ahistorycznej, niemej i niepodlegającej zmianom Natury umożliwia

14 Zob. tamże, s. 37. Morton w kontekście nie-ludzi oraz ich posiadania (dowolnego rozporządzania własnością) analizuje przypadek amerykańskiego dentysty, który wykupił prawo do zabicia jednego z najbardziej znanych zwierząt - Iwa Cecila. Dentysta tym samym naraził się na ostracyzm społeczny, gdyż większość ludzi solidarnie zdecydowała, że mają więcej wspólnego z zabitym zwierzęciem niż z człowiekiem-myśliwym.

15 Zob. T. Morton Dark Ecology: For a Logic of Future Coexistence, Columbia University Press, New York 2016. 
traktowanie nie-ludzi jako bierny, zawsze odnawialny zasób, który można wykorzystywać zgodnie z naszym, ludzkim interesem. Dopiero gdy pozbędziemy się wyobrażenia naturalnej przestrzeni, funkcjonującej niczym pojemnik, wówczas okaże się, że każdy nie-człowiek ma swoją indywidualną, niepowtarzalną historię, własny czas, w rytm którego się starzeje i szereg cech, o jakich prawdopodobnie nigdy się nie dowiemy ${ }^{16}$.

Dlatego Pocahontas może wreszcie przyznać:

Ulewa jest mą siostrą, strumień bratem, a każde z żywych stworzeń to mój druh, Jesteśmy połączonym z sobą światem... ${ }^{17}$

Wspólnota jest możliwa przede wszystkim dzięki temu, że w zasadzie nigdy nie przestała istnieć, gdyż wszyscy są ze sobą połączeni (interconnectedness) ${ }^{18}$. Jedynie ludzie stracili ją na chwilę z oczu, beznadziejnie zapatrzeni w iluzję indywidualizmu i samowystarczalności. Ujawnienie współzależności niweluje wszystkie linie podziału i granicę, jaką między światem ludzi i nie-ludzi pragnie postawić antropocentryczny umysł. Pocahontas chce uświadomić Smithowi, że rzeczywistość ma charakter relacyjny, a w jej wytwarzaniu zawsze uczestniczymy kolektywnie. Filozofia przez wieki chciała postrzegać byty i idee jako istniejące w izolacji, jednak jej projekt od samego początku skazany był na porażkę, a sam okazał się kiepską fantazją i mrzonką. Ludzi i nie-ludzi nie poznajemy wcale poprzez ich substancje (czego domagała się klasyczna myśl filozoficzna), ale raczej przez sieć oddziaływań, którymi są połączone. Jeśli coś nie oddziałuje i nie łączy się z innymi, najprawdopodobniej nie istnieje.

Pocahontas ostatecznie zostawia Smithowi wybór („Możesz zdobyć świat, lecz to będzie tylko świat! Nie barwy, które niesie wiatr..."). Jeśli ten zdecyduje się pozostawać dalej w antropocentrycznej bańce, otrzyma jedynie heideggerowski świat, gdzie marzenia o wyjątkowości przekładają się jedynie głębokiej oraz zgubną ideą powrotu do Natury (całość urwanego przeze mnie wersu po polsku brzmi „jesteśmy połączonym z sobą światem, a natura ten krąg życia wprawia w ruch"). Natomiast w przypadku języka angielskiego („and we are all connected to each other in a circle, in a hoop that never ends") nasza bohaterka konsekwentnie milczy w sprawie Natury, co daje powody ku temu, by mogła być zdecydowaną sojuszniczką Mortona i orędowniczką solidarnej wspólnoty ludzi oraz nie-ludzi. 
na samotność i wyobcowanie. Z kolei opowiedzenie się za świadomym uczestnictwem w rzeczywistości symbiotycznej oznacza jednocześnie zgodę na splecenie swoich ludzkich losów z nie-ludźmi. Odtąd zaczynamy myśleć o sobie jako otoczonych, przenikniętych nie-ludźmi, by w końcu dostrzec, że tak naprawdę jesteśmy z nich zrobieni. Bycie człowiekiem jest nie-ludzkim przedsięwzięciem.

\section{Ciemna ekologia}

Należy podkreślić, że Morton ani przez chwilę nie stara się być filozofem, który proponowałby utopijne idee związane z niemożliwym powrotem do romantycznej wizji harmonijnej i pięknej Natury. Jest raczej zwolennikiem ciemnej ekologii (dark ecology), która przyjmując postać melancholijnej etyki, ujawnia czym jest życie jako współistnienie w obliczu ekologicznej katastrofy. Uświadamia nam, że współcześnie zbyt często przyłączają się do nas nie-ludzie, którzy nie budzą w nas wcale optymistycznych nastrojów, lecz raczej niosą ze sobą ciemność, niepokój i depresję. Jego filozoficzny projekt okazuje się bardzo mocno związany z derridiańską widmontologią (haunto$\operatorname{logy})^{19}$. Myślenie ekologiczne jest z gruntu widmowe, gdyż zakłada zawsze istnienie $(n+1)$ tego, $\mathrm{z}$ czym jesteśmy w jakiś sposób połączeni, nawet jeśli w danej chwili jest to jedynie niewyraźne przeczucie. Na przykład gdy na naszym talerzu pojawia się ryba, najczęściej trudno nam sobie uświadomić, że przybywa wraz z rtęcią, która odtąd staje się częścią naszego organizmu, a każde uruchomienie silnika naszego samochodu wiąże się z nasilaniem się efektu cieplarnianego. Dlatego Morton zaleca nam, byśmy obdarzali miłością rzeczy takie jakimi są naprawdę, zamiast oczekiwać, że ohydna ropucha pod wpływem ekologicznych pocałunków i zabiegów zamieni się w księcia z bajki.

Ekologia nie jest wcale skazana na pięknoduchostwo, eskapistyczny sentymentalizm oraz drzemiący w niej regresywny, by nie powiedzieć bajkowy optymizm, łączący ze sobą fascynację pięknem z moralnością²0. Myślenie ekologiczne, dzięki swojej ciemnej wersji, otwiera się na wykluczaną do tej

Zob. J. Derrida Widma Marksa. Stan długu, praca żałoby i nowa Międzynarodówka, Wydawnictwo Naukowe PWN, przeł. T. Załuski, Warszawa 2016. właśnie romantyczne poczucie estetyki, które czynności związane z kulturą jedzenia mięsa uznaje za obrzydliwe (hodowla zwierząt, ich zabijanie, oprawianie oraz krwistość samego mięsa). Zob. T. Morton Ecology without Nature, s. 111-117. 
pory brzydotę przestrzeni (po)przemysłowych, obrzydliwość industrialnych odpadów oraz irytujący hałas dźwięków miast, dotychczas rozpoznawanych jako zanieczyszczenia niesione przez nowoczesność i znajdujących się po stronie techniki (kultury). Romantyczna wyobraźnia ekologiczna okazuje się przede wszystkim wytworem konsumpcjonizmu, który stara się za jej pomocą poradzić sobie z poczuciem winy, rosnącym wraz z nasilającą się konsumpcją oraz produkcją problematycznych śmieci. Utopijna wizja wewnątrzświatowej, rajskiej harmonii możliwa jest jedynie wówczas, gdy wyobrazimy sobie idylliczną bezczynność - zwierzęta i ludzie wspólnie będą pogrążeni w braku jakiejkolwiek aktywności.

Jeżeli zdecydujemy się spojrzeć na historię Pocahontas oczami Mortona, otrzymamy wówczas opowieść o połączeniu, która proponuje przeżywać najbardziej głębokie ekologiczne doświadczenie bez naiwnego optymizmu, pragnienia piękna oraz uzdrawiającej mocy światła. W tym kontekście warto zwrócić uwagę na to, że Pocahontas umiera w wieku 21 lat, a przyczyną jej śmierci były prawdopodobnie prątki gruźlicy (Mycobacterium tuberculosis) lub wirusy odpowiedzialne za czarną ospę (variola virus), które przedostały się do „Nowego Świata” w ciałach kolonizatorów. Jednak Europejczycy nie tylko przywieźli ze sobą nie-ludzkich aktorów do Ameryki, ale również zabrali ze sobą zupełnie nowych aktywistów i działaczy na „Stary Kontynent”. Jednym z nich był prawdopodobnie krętek blady (Treponema pallidum), który dał znać o swoim istnieniu w postaci epidemii kiły (1494) bezpośrednio po wyprawach Krzysztofa Kolumba ${ }^{21}$.

W klasycznym odczytaniu Pocahontas, wystarczy jedynie przestać być człowiekiem, aby stać się ludzkim i nawiązać wspólnotę z nie-ludzmi, którzy przedstawiani są najczęściej jako piękni i niezwykle estetyczni, czyli godni ludzkiego pożądania. Tymczasem Morton w swojej „ciemnej ekologii” proponuje nam nie tylko połączyć się z tym, co odrażające i obrzydliwe, ale przede wszystkim odnaleźć to w sobie samych. Zamiast zgodnie z antropocentryczną mesjańską wizją starać się wyciągnąć świat z bagna, lepiej samemu do niego wejść i sprawdzić, co w nim się kryje. Ulubioną figurą i jednocześnie zapowiedzią innej, nie-ludzkiej wspólnoty jest dla Mortona Frankenstein, czyli budząca wstręt hybryda utkana z byle jakiego ciała (any body), czyli tego, co wirusów, które okazują się niezwykle twórcze, gdyż charakteryzują się dużą zmiennością genetyczną, ale jednocześnie równie dokuczliwe (bardzo wysoka gorączka, drgawki, bóle mięśni igłowy). 
odrzucone, a jednocześnie niezwykle towarzyskie i spragnione kontaktu²2. Co stanie się, jeśli stracimy Naturę? Zyskamy przede wszystkim towarzystwo, niezwykle aktywny kolektyw, zgromadzenie nie-ludzi, które budzi w nas obrzydzenie i przerażenie, a im bardziej chcemy się go pozbyć, tym z większą mocą lgnie do nas.

\section{Abstract}

\section{Andrzej Marzec}

ADAM MICKIEWICZ UNIVERSITY (POZNAŃ)

'We Are All Connected to Each Other': Timothy Morton and the Spectre of Another Community

Marzec analyses the phenomenon of non-humans disappearing in black boxes (Bruno Latour), withdrawing into handiness (Martin Heidegger/Graham Harman) and their dissolving in Nature (Timothy Morton). Looking for the cause for the catastrophic distinction between humans and non-humans, Marzec finds answers in Morton's philosophical tools. A key reason the distinction between humans and non-humans is the transition from the gathering and hunting collective to the agricultural community - a transition that gives rise to agrilogistics or thinking about non-humans in terms of resources or private property. Marzec explores the notion of ecology without the notion of Nature and uses Morton's concept of dark ecology to outline the possibilities of another community in solidarity with non-humans.

\section{Keywords}

non-humans, ontology focused on objects, Timothy Morton, dark ecology, ecology without Nature 